\title{
International economics and natural resources: from theory to policy
}

\author{
Lucas Bretschger • Simone Valente
}

Published online: 6 May 2011

(C) Springer-Verlag 2011

\section{Introduction}

In the last two centuries, international trade and technical progress have been crucial drivers of economic development. However, the functioning of modern economies still hinges on the use of natural resources like fossil fuels and minerals. Since the supplies of these resources are very unevenly distributed among countries, resource trade has become an important part of globalization. In particular, many industrialized economies heavily depend on imports from resource-rich countries. The dominance of natural resource extraction in certain national economies creates specific risks and opportunities for development and competitiveness. Many resources are exhaustible, which is a reason why their prices are generally highly volatile and expected to further rise in the future. Price volatility and trends will have a major impact on the trade positions and the terms of trade of resource-exporting and -importing economies. Another aspect of natural resources is the pollution of the environment associated with their use. In principle, appropriate environmental policies can correct for the market failure of negative externalities. But in open economies, governments tend to choose sub-optimal policies because they fear a loss of competitiveness of domestic industries.

The issue of natural resource scarcity in a globalized world raises several fundamental issues for economic research. It is important to know how resource dependence affects trade patterns and the relative economic performance of both resource-rich and resource-poor economies. Therefore, the analysis should not only cover long-run equilibria but also the adjustment processes, for example after new resource discoveries. Specifically, we should

L. Bretschger $(\bowtie) \cdot$ S. Valente

CER-ETH Centre of Economic Research, ETH Zurich, ZUE F7, 8092 Zurich, Switzerland e-mail: lbretschger@ethz.ch 
gain knowledge about the positive and the negative growth effects of resource endowments and resource shocks in open economies. Moreover, trade in essential primary inputs obtained from natural resources generates peculiar incentives for national governments to implement strategic policies that interact with traditional trade policies. Uncooperative trade policies are very likely with scarce natural resources, which has an unfavourable impact on global prosperity. Finally, in order to measure welfare and to predict sustainability of development, natural resource use in open economies is an especially demanding topic.

Below, we summarize the findings of the previous literature and present novel aspects and results of the current debate, introducing the contributions to the present special issue of International Economics and Economic Policy entitled "International Economics and Natural Resources: From Theory to Policy."

\section{The state of the art}

For a long time, research in international economics was largely disconnected from environmental and resource problems. In the 1980s and 1990s, a first wave of literature turned to general equilibrium models, where explicit allowance was made for trade and exhaustible resources, see especially Kemp and Long (1980) and Chiarella (1980). In the contribution of Van Geldrop and Withagen (1993), trade in raw materials from exhaustible natural resources is analyzed within a general equilibrium approach. Many standard results from the theory of international trade are shown to remain valid with natural resources. In addition, the conditions for a constant interest rate are identified, which is an often-used assumption in (partial equilibrium) models of natural resource depletion.

More recent contributions have focused on the impact of resource efficiency on economic development, see the contributions in the special issue of International Economics and Economic Policy by Bleischwitz et al. (2010). Daubanes and Grimaud (2010) study the effects of taxes on polluting resources with trade between resource-rich and resource-poor economies. They conclude that such a tax can correct the global environmental problem. But, even when the countries coordinate their taxation policies, their divergent strategic interests cause other distortions in the international allocation of the resource. Bretschger and Valente (2010) observe that the aggregate income of oil-exporting countries relative to that of oil-poor countries is remarkably constant over time. They develop a model in which the terms-of-trade effects are the mechanism that explains this result. Moreover, the paper shows that oil-importing countries can raise their income share by raising the national tax on domestic resource use.

A second strand of literature focuses on the pollution effects of resource use in trading economies. These contributions ask whether a country should adopt a restrictive trade policy in order to better protect its natural environment and 
whether trade policy could be used to correct for environmental problems. Antweiler et al. (2001) distinguish between two favorable effects of trade, the technique and the scale effect, and an unfavorable effect, reflecting increasing pollution concentration in an economy. They present empirical evidence showing that the positive effects dominate, so that freer trade turns out to be good for the environment. The relationship between trade and environmental policy is the subject of Copeland and Taylor (2004). It emerges that both trade and investments are influenced by pollution regulations. But at the same time, it is argued that factors other than differences in environmental policies are more important in determining trade patterns. Whether trade policy should be used to achieve environmental objectives either at home or abroad is highly disputed. The direct effects could go in the targeted direction, that is a country importing goods produced with polluting inputs can possibly punish the exporting country. But there are a series of indirect effects, both in the macroeconomic and in the political context (e.g. retaliation), which may counteract the direct effect.

It should also be noted that international organizations are devoting increasing attention to the topic of resource trade. Prominently, the World Trade Organization (WTO) has recently completed an extensive report on the role of resource trade, see WTO (2010). The report provides a valuable and comprehensive survey of the current macroeconomic issues in resource trade. It concludes that, due to the importance of natural resources, the governments of all countries should cooperate more closely to ensure appropriate resource management and mutual gains from trade and regulations.

\section{The current debate}

A recurrent theme of natural resource use is its impact on economic development. A large endowment of natural resources may lead to political instability, corruption, and conflicts, because different political groups have an incentive to fight for obtaining the resource rents. However, appropriate institutions can help an economy to direct resource rents into a productive and growthenhancing direction, see Brunnschweiler and Bulte (2008). International trade is an important ingredient for obtaining sub-optimal results, even when the (beneficial) gains from trade are one of the most agreed results in economic theory. The problem is that international trade can act as a magnification effect of domestic market and policy failures. An obvious case is open access with natural resources, where the internationalization of an economy accelerates resource depletion and thereby amplifies the externalities associated with it. Moreover, resource exports allow to increase resource rents which can amplify conflicts and lead to excessive international borrowing. Yet, in a multi-sector economy, another unfavourable effect of natural resource endowments is deindustrialization of the economy because foreign trade allows to extend the resource sector at the expense of manufacturing. If this sectoral change follows a new resource discovery and entails a negative impact on development, 
the phenomenon is usually labelled "Dutch disease." The assesment of the causes and consequences of this phenomenon is the first topic covered in the contributions to the present special issue of International Economics and Economic Policy.

The Dutch Disease is reconsidered in Van der Ploeg (2011) with the help of a dynamic model including three sectors that differ with respect to input intensities. It is shown that sector-specific factors are the key to explain the behaviour of the exchange rate and other macroeconomic variables in response to a natural resource windfall. If the resource windfall is substantial but not too big, capital must be produced at home, and this process takes time. The resource boom triggers a reallocation, whereby factors are gradually shifted out of manufacturing and the real exchange rate appreciates, yielding a negative impact on development. However, if the windfall is large and the resourcerich economy is relatively small, there is another option to avoid the Dutch disease: the country may import sufficient capital and migrant labour from abroad, in order to circumvent its own absorption constraints. With respect to economic policy, Van der Ploeg (2011) discusses two scenarios. In the first scenario, the country follows a permanent-income fiscal rule-i.e., it borrows ahead of the windfall and then builds up sovereign wealth that eventually yields a positive net interest to be spent on additional consumption. The second scenario is the bird-in-hand fiscal rule whereby the sovereign wealth created by the windfall is parked in a fund from which a fixed percentage is drawn to finance consumption. It is argued that many developing countries would benefit from the bird-in-hand rule as it alleviates the absorption constraints generated by slow domestic capital accumulation.

Beverelli et al. (2011) extend the standard model of the Dutch disease to include input-output linkages between the manufacturing and the natural resource sectors, and consider many industrialized sectors characterized by different energy intensity. The authors show that oil discoveries do not necessarily lead to Dutch disease, because the positive effects on the productivity of the sectors that use oil more intensively counteracts the appreciation of the real exchange rate, and thus alleviates the negative feedback effects from foreign trade. The authors provide empirical evidence for the relevance of this sectoral adjustment effect.

Davis (2011) reconsiders the hypothesis that resource-rich economies grow more slowly than other countries because of the crowding out of activities with positive production externalities, a main explanation for the so-called "resource curse". The main alternative hypothesis he proposes is the "resource drag": energy and resource sectors exhibit modest growth rates in per capita production under standard efficiency conditions, so that resources are optimally managed but introduce a drag on the measured growth of per capita economic output. In his empirical study of a broad country sample, the author finds support for this hypothesis. The implication is that a rise or fall in mineral production does not in itself warrant corrective trade or industrial policies 
aimed at changing the mineral production profile. If boom-bust growth cycles are generated by the resource drag, policies motivated by the existence of growth-reducing market failures should be carefully considered.

Two other important topics connected to resource trade concern the macroeconomic effects of trade policy and the sustainability of resource-rich economies that are open to international trade. Latina et al. (2011) analyse the specific conditions of trade policy in the case of natural resources. They stress that, in natural resource sectors, export taxes are often encountered while import tariff protection is generally low. Asymmetric trade regulation may lead to uncooperative outcomes which appear to be attractive for a single country but are not efficient at the global level. As a solution, the paper argues that countries should exchange commitments on export taxes against lower binding tariffs in downstream sectors: these negotiations would reduce inefficiencies and allow trade to grow.

In order to evaluate whether the current patterns of economic activity, trade and resource use are sustainable in the long run, Bretschger and Valente (2011) develop a formal rule for augmented net investment, which explicitly refers to trade and technical progress. Methodologically, this leads to a separate calculation of the value of time. The authors stress that future consumption growth due to technical progress and the rental income from exported resources entail major corrections of the investment rates. The rule is applied to the world's top 20 oil producers. It is found that the difference between augmented and non-augmented measures of net investment can be huge and may even revert previous conclusions on sustainability. Moreover, international trade is a major factor driving the results. For six countries, the present value rental income from future exports is estimated to be above 60 percent of current gross national income and thus represents a substantial fraction of the calculated value of time.

In conclusion, we stress that development in resource-rich open economies includes complex relationships between economic agents, institutions and the environment, so that general policy recommendations cannot be derived in a straightforward manner. Nevertheless, it needs to be recalled that the gains from trade have been one of the major sources of welfare growth for more than two centuries. The effects of both comparative advantage and international division of labour have had positive impacts on income levels and economic growth rates. Moreover, the competition of political systems and institutions between the countries has positive efficiency effects. But, as we noted above, in the case of incomplete markets and external effects, international trade can magnify domestic problems and inefficiencies. It is on these grounds that the tendency to blame trade and "globalization" for the problems has become widespread in the public debate. Economists are therefore required to show avenues for an improvement of economic development with natural resources beyond the simplistic suggestion of restricting international trade. 


\section{References}

Antweiler W, Copeland BR, Taylor MS (2001) Is free trade good for the environment? Am Econ Rev 91(4):877-908

Beverelli C, Dell'Erba S, Rocha N (2011) Dutch disease revisited, oil discoveries and movements of the real exchange rate when manufacturing is resource-intensive. International Economics and Economic Policy, this issue

Bleischwitz R, Welfens PJJ, Zhang Z-X (2010) The International Economics of Resources and Resource Policy. Special Issue of International Economics and Economic Policy 7(2/3):141151

Bretschger L, Valente S (2011) International trade and net investment. International Economics and Economic Policy, this issue

Bretschger L, Valente S (2010) Endogenous growth, asymmetric trade and resource taxation. Economics Working Paper Series 10/132, ETH Zurich

Brunnschweiler CN, Bulte EH (2008) The resource curse revisited and revised: a tale of paradoxes and red herrings. J Environ Econ Manage 55(3):248-264

Chiarella C (1980) Trade between resource-poor and resource-rich economies as a differential game. In: Kemp MC, Long NV (eds) Exhaustible resources, optimality and trade, NorthHolland, Amsterdam, pp 219-246

Copeland BR, Taylor MS (2004) Trade, Growth, and the Environment. J Econ Lit 42(1):7-71

Daubanes J, Grimaud A (2010) Taxation of a Polluting Non-renewable Resource in the Heterogeneous World. Environ Resour Econ 47(4):567-588

Davis GH (2011) The Resource Drag. International Economics and Economic Policy, this issue

Kemp MC, Long NV (1980) The interaction of resource-rich and resource-poor economies. In: Kemp MC, Long NV (eds) Exhaustible resources, optimality and trade, North-Holland, Amsterdam, pp 197-210

Latina J, Piermartini R, Ruta M (2011) Resource trade wars. International Economics and Economic Policy, this issue

Van Geldrop J, Withagen C (1993) General Equilibrium and International Trade with Exhaustible Resources. J Int Econ 34(3-4):341-357

Van der Ploeg F (2011) Fiscal policy and Dutch disease. International Economics and Economic Policy, this issue

World Trade Organization/WTO (2010) World Trade Report. Trade in Natural Resources, Geneva 